\title{
Molecular Characterisation and Phylogenetic Analysis of Dermatophytic Fungi Isolated from Tinea Capitis in Northwest Nigeria Using Sequence of the $28 S$ rRNA
}

\author{
Hussain Yahaya Ungo-kore ${ }^{1, *(\mathbb{D})}$, Joseph Olorunmola Ehinmidu ${ }^{2}$, Josiah Ademola Onaolapo ${ }^{2}$ \\ and Olayeni Stephen Olonitola ${ }^{3}$ \\ 1 Department of Pharmaceutics and Pharmaceutical Microbiology, Faculty of Pharmaceutical Sciences, \\ Usmanu Danfodiyo University, Sokoto 2346, Nigeria \\ 2 Department of Pharmaceutical Microbiology, Faculty of Pharmaceutical Sciences, Ahmadu Bello University, \\ Zaria, Kaduna 1044, Nigeria; ehinmidu1953@yahoo.com (J.O.E.); jaonaolapo@gmail.com (J.A.O.) \\ 3 Department of Microbiology, Faculty of Life Sciences, Ahmadu Bello University, Zaria, Kaduna 1044, Nigeria; \\ olonisteve@gmail.com \\ * Correspondence: hussaini.yahaya@udusok.edu.ng; Tel.: +234-8033647999
}

\section{check for} updates

Citation: Ungo-kore, H.Y.; Ehinmidu, J.O.; Onaolapo, J.A.; Olonitola, O.S. Molecular Characterisation and Phylogenetic Analysis of

Dermatophytic Fungi Isolated from Tinea Capitis in Northwest Nigeria Using Sequence of the $28 S$ rRNA. Microbiol. Res. 2021, 12, 646-655. https://doi.org/10.3390/ microbiolres 12030046

Academic Editor: Luca Grispoldi

Received: 4 March 2021

Accepted: 6 April 2021

Published: 1 August 2021

Publisher's Note: MDPI stays neutral with regard to jurisdictional claims in published maps and institutional affiliations.

Copyright: (c) 2021 by the authors. Licensee MDPI, Basel, Switzerland. This article is an open access article distributed under the terms and conditions of the Creative Commons Attribution (CC BY) license (https:/ / creativecommons.org/licenses/by/ $4.0 /)$.

\begin{abstract}
The detection and identification of fungal DNA from clinical samples is one of the fundamental approaches in biomedicine. The incidence, distribution, and control of dermatophytes has progress significantly and the use of phylogenetic species concepts based on rRNA regions have enhanced the taxonomy of dermatophyte species; however, the use of $28 S \mathrm{rDNA}$ genes has certain limitations. This gene has been used in dermatophyte taxonomy with limited enumeration; we appraised the sequence disparity within and among groups of the species, the gene ranking in identification, phylogenetic analysis, and taxonomy of 32 strains of eight dermatophyte species. In this study, a set of primers was adopted to amplify the target followed by a partial sequencing of the $r D N A$. The utilization of a pairwise nucleotide differentiation, an affinity was observed among eight dermatophyte species, with disparity among species ranging from 0 to 197 base pair (bp). Intra-species bp differences were found within strains of Trichophyton eriotrephon, Trichophyton bullosum, Trichophyton simii (Trichophyton genus), Microsporum audouinii, and Trichophyton tonsurans (Microsporum and Trichophyton genus, respectively); however, only some strains of Trichophyton eriotrephon were found to be invariant having three genotypes. Trichophyton tonsurans exhibited most intra-species variability. The characterization and construction of a phylogenetic tree of $28 \mathrm{~S}$ $r D N A$ gene on dermatophyte species provide a bedrock of an additional finding of connections between species. However, $28 S$ rRNA capture provides a novel method of effective and sensitive detection of dermatophytes lodged in human skin scale. We report for the first time the emergence of T. eriotrephon, T. bullosum, T. simii, T. benhamiae, and Ctenomyces serratus dermatophytes from Tinea capitis in Nigeria.
\end{abstract}

Keywords: Tinea capitis; $28 S$ rDNA gene; phylogenetics; Sokoto; Trichophyton; Ctenomyces

\section{Lay Abstract}

The incidence, distribution, and control of dermatophytes has progress significantly and a superior knowledge of the phylogenetic understanding of dermatophytes may provide a master plan in preventing Tinea capitis transmission and infection, thus treatment. Few studies have reported on the molecular characterization of dermatophytes in Nigeria and not much attempt has been set down into the phylogenetic analysis, statistics, and subsequent submission of these sequence into gene repositories (https:/ / www.ncbi.nlm.nih. gov / nuccore?term=MT893932+\%3A+MT893963\%5Baccn\%5D\&cmd=DetailsSearch\&log $\$=$ activity, accessed on 27 August 2020). To the best of our understanding, this study is the first of its kind in Sokoto, successfully depositing nucleotide sequences of dermatophyte 
strains into the GenBank database. This was done to further populate the Genebank database, particularly using $28 S$ rRNA, whose information is limited.

\section{Introduction}

Dermatophytes are a group of fungi with a genera consisting of Trichophyton, Microsporum, and Epidermophyton that causes dermatophytosis by influencing keratinised tissues (skin, scalp, hair, and nails) of human and animal hosts [1]. The species of dermatophytes, which tend to cause scalp ringworm, may differ from country-to-country and from region-to-region [2].

Tinea capitis is a dermatophytosis of the hair and scalp skin, correlated with clinical symptoms and signs of inflammation and hair loss, which includes thickened, scaly, and boggy swellings, or as raised red rings (ringworm). Others are severe itching of the scalp, dandruff, and bald patches, where the fungus has rooted itself in the skin [3]. Sources of ringworm include anthropophilic, zoophilic, and geophilic, and is highly contagious amongst children, especially school pupils, with rare reports in adults [4]. The epidemiology and prevalence of this infection varies among regions, populations, lifestyles, migration, drug therapies, and socioeconomic conditions [5]. Microsporum audouinii and Microsporum canis have been reported to be the main causative agents in western and Mediterranean Europe while Trichophyton species (T. schoenleinii) is the most prevalent agent in Eastern Europe and Africa [6].

Characterisation, identification, and classification of dermatophytes were conducted conventionally by the use of clinical and gross examination of colonies from culture, microscopically (macro- and micro-conidia). The use of biochemical testing is used as confirmation. However, this method of characterisation is time-consuming and needs experts to interpret results of the morphology [7]. The use of recent molecular methods of characterisation of the polymerase chain reaction (PCR) technique has provided a faster, accurate, and reliable means of identification, especially in infections directly from nail fragments, since it is possibly the most complex structure of the skin [8]. DNA fragments have been noticed as the main dermatophyte genetic markers (ribosomal DNA) regions [9]. The $28 \mathrm{~S} r \mathrm{DNA}$ regions are a good balance for detecting differences between conservancy and variability in organisms and are, hence, potentially useful markers to study the relationships of populations and closely related species in microorganisms. However, they are scarce in databases. The goal of the study is to (i) recognise the prevalence and phylogenetic affiliation among dermatophyte strains of Tinea capitis from primary school pupils in Sokoto State-owned primary schools, with a view to ascertain the genetic diversity, conservancy, and variability of the strains based on $28 S r R N A$ gene sequencing. (ii) Phylogenetic relationships of $28 S r R N A$ gene analysis in the segregation of anthropophilic from zoophilic dermatophytes.

\section{Materials and Methods}

\subsection{Study Centre}

The present research work was carried out on strains from Sokoto State, located in the extreme northwest of Nigeria, between longitudes $4^{\circ} 8^{\prime}$ and $6^{\circ} 54^{\prime}$ and latitude $12^{\circ} \mathrm{N}$ and $13^{\circ} 58^{\prime} \mathrm{N}$. The state has a population of nearly 5.4 million people, covers a terrestrial area of $32,000 \mathrm{~km}$, and shares a border with the Republic of Niger. The major ethnic groups in the state are the Hausa and Fulani groups. Over 80 percent of the people in the state practice agriculture (husbandry and crops) as their major source of income [10].

\subsection{Dermatophyte Clinical Strains}

In this study, an ethical permission was obtained from the Sokoto State Ministry of Health Ethical Committee (SKHREC/088/017) and informed consent was obtained from all participants involved in the study. Clinical strains obtained from the heads of 125 participants (boys and girls between the ages of 4 and 10) presented with scaling and/or hair loss was suggestive of Tinea capitis and typically had two or more of pruritus, hair 
loss, scaling, erythema, and posterior cervical adenopathy from the Sokoto state-owned primary school. Study participants were excluded if a kerion was present. Affected areas were cleansed with $70 \% v / v$ ethanol, allowed to dry, and light scrapings from the edge of the lesions were taken using a blunt sterile scalpel blade. The specimens were placed in clean white envelopes with each participant code labelled. Clinical strains were selected for sequencing after being previously characterised using standard microbiological procedures $(10 \% \mathrm{KOH}$, cycloheximide and chloramphenicol, urea hydrolysis, $1 \%$ peptone agar, and the 40 strains of dermatophytes were cultured onto the Sabouraud dextrose agar (SDA) at $32{ }^{\circ} \mathrm{C}$ for up to 2 weeks), DNA extraction, and PCR amplification.

\subsection{Dermatophyte DNA Extraction and PCR Amplification}

Genomic DNA was harvested using Qiagen (Hilden, Germany) DNA extraction kit in adherence to the manufacturer's protocols; Aliquot volume containing culture micelles from colonies cultured from SDA were sampled $\left(1-3 \times 10^{5}\right)$ and transferred to a $1.5 \mathrm{~mL}$ e-tube, and centrifuged at 10,000 rpm for $7 \mathrm{~min}$. The supernatant was poured off and the cells were re-suspended with Hank's balanced salt solution in a total volume of $200 \mu \mathrm{L}$. The samples were freeze on pellets in a $-80^{\circ} \mathrm{C}$ freezer for $60 \mathrm{~min}$. Qiagen Proteinase $\mathrm{K}$ of $20 \mu \mathrm{L}$ was pipetted into the bottom of a $1.5 \mathrm{~mL}$ microcentrifuge tube and $200 \mu \mathrm{L}$ of both cell suspension and Buffer AL were added. This was vortex for $15 \mathrm{~s}$ and incubated in a $56{ }^{\circ} \mathrm{C}$ water bath for $10 \mathrm{~min}$. The content were centrifuged to remove droplets formed at the top. Ethanol (100\%) of $200 \mu \mathrm{L}$ was added to the content of the mixture and mix by vortexing for $15 \mathrm{~s}$ and briefly centrifuged, which was later added the to a QIAamp spin column and again centrifuged at 13,200 rpm in the Eppendorf 5415R microcentrifuge for $1 \mathrm{~min}$ at room temperature. Buffer AW1 $(500 \mu \mathrm{L})$ was added to the Eppendorf 5415R microcentrifuge containing residual contaminants and centrifuged at 10,000 rpm for $1 \mathrm{~min}$ at room temperature. The spin column was removed and place in another clean, labelled collection tube, of which $500 \mu \mathrm{L}$ of Buffer AW2 was added and centrifuged at 13,200 rpm in the Eppendorf 5415R microcentrifuge, for $3 \mathrm{~min}$ at room temperature. The concentration of the extracted DNA was measured with the NanoDrop spectrophotometer ND-1000 and $50 \mathrm{ng}$ was taken for use in PCR. For each strain, DNA fragment (about $298 \mathrm{bp}$ ) of the $28 \mathrm{~S}$ rRNA gene were amplified using $28 \mathrm{~S}$ rRNA primer of forward 5'-ACAGGGATTGCCCCAGTA-3' ${ }^{\prime}$,reverse 5'-CTTGTTCGCTATCGGTCTC-3', according to methods previously described by Kim et al. [11].

A total of $25 \mu \mathrm{L}$ volume contained $12.5 \mu \mathrm{L}$ of Qiagen Top Taq master mix, $1 \mu \mathrm{L}$ of each primer, $5.5 \mu \mathrm{L}$ of nuclease free water, and $5 \mu \mathrm{L}$ of DNA template. The reaction mix was centrifuged briefly and transferred to the thermocycler at $3 \mathrm{~min}$ of hot-start at $94{ }^{\circ} \mathrm{C}, 30 \mathrm{~s}$ of denaturation at $94{ }^{\circ} \mathrm{C}, 30 \mathrm{~s}$ of annealing at $50{ }^{\circ} \mathrm{C}$, and $1 \mathrm{~min}$ of extension at $72{ }^{\circ} \mathrm{C}$. The entire process was repeated for 35 cycles, with the final extension at $72{ }^{\circ} \mathrm{C}$ for $10 \mathrm{~min}$.

\subsection{Sequencing}

The amplicons were re-amplified and purified using Qiagen DNA kits according to the manufacturer's recommendations. The purified PCR products were packaged and sent for Sanger sequencing at Inqaba Biotec South Africa.

\subsection{Nucleotide Blast}

The $28 S$ rRNA sequence data obtained were entered into the Basic Local Alignment Search Tool (BLASTN) of the National Centre for Biotechnology Information (NCBI) database and compared with information provided by Centraalbureau voor Schimmelcultures (CBS).

\subsection{Sequence Analysis}

The sequence (forward and reverse) chromatograms of each sample were amended to improve the alignment precision using MEGA 7 software; BioEdit software version 7.0.5 was used for pairwise contrast and multiple alignment to determine similarities and differ- 
ences among the nucleotides. Pairwise affinity values were calculated and phylogenetic trees were constructed using the neighbour-joining (NJ) method with the Tamura-Nei parameter as a substitution model, as implemented in MEGA 7. The reliability of internal branches was assessed using the bootstrap method with 500 replicates. The consensus nucleotide sequence data determined in this study were deposited in the GenBank under the accession numbers MT893932-MT893963 (Table 1).

Table 1. Clinical strains and accession number of dermatophytes used in this study.

\begin{tabular}{ccc}
\hline Accession Number & Organism & Isolate ID (Ugk) \\
\hline MT893932-MT893941 & Trichophyton eriotrephon & $1,7,10,14,16,19,20,22,31,40$ \\
\hline MT8939342-MT893943 & Trichophyton bullosum & 2,23 \\
\hline MT893944-MT893955 & Trichophyton simii & $3,4,5,6,8,9,15,24,26,29,34,37$ \\
\hline MT893956 & Trichophyton benhamiae & 11 \\
\hline MT893957 & Trichophyton rubrum & 13 \\
\hline MT893958-MT893960 & Trichophyton tonsurans & $33,35,39$ \\
\hline MT893961-MT893962 & Microsporum audouinii & 30,32 \\
\hline MT893963 & Ctenomyces serratus & 38 \\
\hline
\end{tabular}

\section{Results}

The use of $28 S$ rRNA gene sequences for differentiation and phylogenetic studies of the dermatophytes species was achieved using a part of the gene that was amplified for 32 strains, with sizes of the region ranging from 239 to 347 base pair (bp). Partial sequences of approximately 809-1350 bp, corresponding to the smaller sub-unit of gene $28 \mathrm{~S} r R N A$, were obtained from the GenBank and aligned with the study sequences. The smallest size was found in Trichophyton simii, comprising of $239 \mathrm{bp}$, and the longest in Trichophyton tonsurans with $347 \mathrm{bp}$. Most of the Trichophyton species had identical sizes, between 247 and 248 bp.

Multiple sequence alignment showed a fundamental heterogeneity within species of dermatophytes. Figure 1 shows the multiple sequence alignment of $28 \mathrm{~S} r R N A$ gene in these dermatophytes with an evolutionarily conserved nucleotide region of 239-245, which could be useful in designing a primer used in dermatophyte characterisation, while genetic variance is seen to be limited to fragments of 1-111, 116-159, 166-184, 191-193, 199-204, 209-215, and 230-239. Conserved regions found within intra-species of T. eriotrephon (221-234 bp), T. bullosum (114-137 bp), T. simii (61-81, 121-155 and 194-212 bp), T. tonsurans (17-26 and 152-161 bp), and M. audouinii (60-80, 90-157, 172-190, and 193-249 bp) as seen in Table 2. Pairwise nucleotide alignment of $28 S$ rRNA gene sequences in tested dermatophytes showed a mean distance of $0.17 \pm 0.03$ between the species; this is shown in Table 3. Interspecies divergence ranged from $0 \mathrm{bp}$ between some strains of T. eriotrephon (Ugk 16) and T. bullosum (Ugk 2), to $197 \mathrm{bp}$ between T. tonsurans and M. audouinii (197 bp), which conform to the largest distance that was observed between T. tonsurans (Ugk 39) and M. audouinii (Ugk 32). The nucleotide sequences of T. eriotrephon and T. bullosum were identical (Ugk 2, 10, 16, and 22). Meanwhile, the intra-species differences were found within strains of T. eriotrephon, T. bullosum, T. simii, M. audouinii, and T. tonsurans by $0-81$ (Ugk 10/22 at 0 bp, Ugk 1/14 at 81 bp), 41 bp (Ugk 2/23), 2-42 bp (Ugk 6/3, Ugk3/8, Ugk $4 / 6$ at 2 bp and Ugk 34/29 at 42 bp), 30 bp (Ugk 30/32 at 30 bp), and 13-192 bp (Ugk 33/35 at 13 bp, Ugk 35/39 at 192 bp), respectively (Table 3); however, only strains of T. eriotrephon (Ugk 10, 16 and 22) were found to be invariant, having three $28 S$ rRNA genotypes. T. tonsurans exhibited most intra-species variability. 
T.eriotrephon(ugk16) T.bullosum(ugk T.simi(ugk34) .benhamiae(ugk11) T.rubrum(ugk13) M.audouinii(ugk32) T.tonsurans(ugk39) C.serratus(ugk38)

T.eriotrephon(ugk16) T.bullosum(ugk2) T.simi(ugk34) .benhamiae(ugk11) rubrum(ugk13) M.audouinii(ugk32) .tonsurans(ugk39) C.serratus(ugk38)

T.eriotrephon(ugk16) .bullosum(ugk2) T.simi(ugk34) .benhamiae(ugk11) rubrum(ugk13) M.audouinii(ugk32) T.tonsurans(ugk39)

T.eriotrephon(ugk16) T.bullosum(ugk2) T.simi(ugk34) T.benhamiae(ugk11) T.rubrum(ugk13) M.audouinil(ugk32) M.audouinil(ugk32) T.tonsurans(ugk39) C.serratus(ugk38)

T.eriotrephon(ugk16)
T.bullosum(ugk2)
T.simi(ugk34)
T.benhamiae(ugk11)
T.rubrum(ugk13)
M.audouinii(ugk32)
T.tonsurans(ugk39)
C.serratus(ugk38)

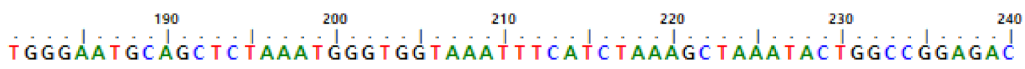

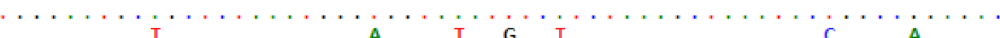

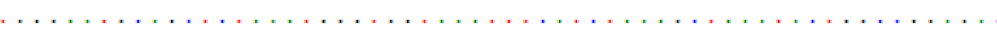

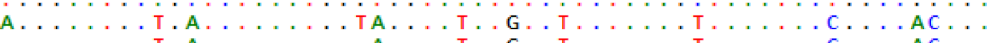
$\because$ T.

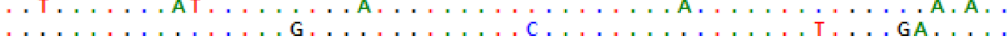

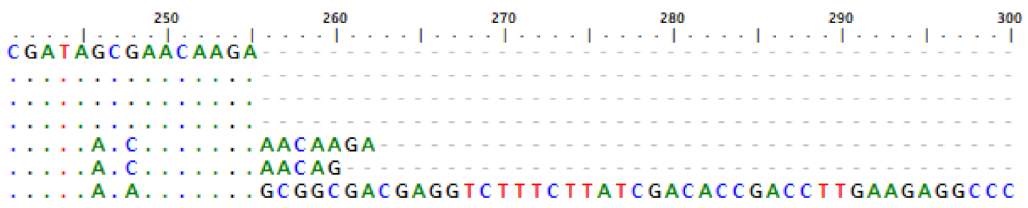

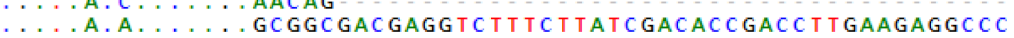
$310 \ldots . . .320$

T.eriotrephon(ugk16) T.bullosum(ugk2) T.simi(ugk34)

T.benhamiae(ugk11)

T.rubrum(ugk13)

M.audouinii(ugk32)

T.tonsurans(ugk39) C.serratus(ugk38)

CTGAATGGCT TGCCGAAT T TGC CACCCTGCGCGCCGAGACCGATAGCGAACAAGA

Figure 1. Multiple sequence alignment of eight (8) nucleotide sequences of the $28 S r R N A$ gene of dermatophytes isolates from Sokoto. The coloured bases indicate regions of nucleotides diversity among isolates. The identical residues are represented with dots. The sequence layout is set to wrap at every 60 residues.

Table 2. Clinical isolated species of dermatophytes used in this study for partial sequence analysis of the $28 S \mathrm{rRNA}$ gene, fragment size, and the range of intra-species variations and conserved regions within the species, are shown.

\begin{tabular}{cccc}
\hline Species (Tested Strain Number) & LS (bp) & Range of Intra-Species Variations & Intra-Species Conserved Region \\
\hline T. eriotrephon (10) & $247-253$ & $0-81$ & $221-234$ \\
\hline T. bullosum (2) & $248-249$ & 41 & $114-137$ \\
\hline T. simii (12) & $239-251$ & $2-42$ & $61-81,121-155,194-212$ \\
\hline T. benhamiae (1) & 250 & - & - \\
\hline T. rubrum (1) & 248 & - & $17-26,152-161$ \\
\hline T. tonsurans (3) & $247-347$ & $13-192$ & $60-80,90-157,172-190,193-249$ \\
\hline M. audouinii (2) & $248-251$ & 30 & -
\end{tabular}

LS: Sequence length or fragment size; -: Not applicable. 
Table 3. Sequence differences based on pairwise sequence comparison of $28 \mathrm{~S}$ rDNA gene between dermatophytes.

\begin{tabular}{|c|c|c|c|c|c|c|c|c|c|c|c|c|c|c|c|c|c|c|c|c|c|c|c|c|c|c|c|c|c|c|c|c|c|}
\hline & Seq-> & 1 & 2 & 3 & 4 & 5 & 6 & 7 & 8 & 9 & 10 & 11 & 12 & 13 & 14 & 15 & 16 & 17 & 18 & 19 & 20 & 21 & 22 & 23 & 24 & 25 & 26 & 27 & 28 & 29 & 30 & 31 & 32 \\
\hline 1 & ugk1 & ID & & & & & & & & & & & & & & & & & & & & & & & & & & & & & & & \\
\hline 2 & ugk2 & 20 & ID & & & & & & & & & & & & & & & & & & & & & & & & & & & & & & \\
\hline 3 & ugk3 & 66 & 56 & ID & & & & & & & & & & & & & & & & & & & & & & & & & & & & & \\
\hline 4 & ugk4 & 66 & 56 & 2 & ID & & & & & & & & & & & & & & & & & & & & & & & & & & & & \\
\hline 5 & ugk5 & 71 & 59 & 10 & 10 & ID & & & & & & & & & & & & & & & & & & & & & & & & & & & \\
\hline 6 & ugk6 & 66 & 57 & 2 & 2 & 9 & ID & & & & & & & & & & & & & & & & & & & & & & & & & & \\
\hline 7 & ugk7 & 72 & 60 & 89 & 90 & 93 & 89 & ID & & & & & & & & & & & & & & & & & & & & & & & & & \\
\hline 8 & ugk8 & 66 & 57 & 2 & 4 & 9 & 2 & 88 & ID & & & & & & & & & & & & & & & & & & & & & & & & \\
\hline 9 & ugk9 & 66 & 58 & 6 & 6 & 12 & 8 & 94 & 8 & ID & & & & & & & & & & & & & & & & & & & & & & & \\
\hline 10 & ugk10 & 20 & 1 & 57 & 57 & 58 & 56 & 59 & 56 & 59 & ID & & & & & & & & & & & & & & & & & & & & & & \\
\hline 11 & ugk11 & 22 & 7 & 58 & 58 & 60 & 57 & 62 & 58 & 57 & 7 & ID & & & & & & & & & & & & & & & & & & & & & \\
\hline 12 & ugk13 & 94 & 85 & 35 & 37 & 43 & 35 & 91 & 35 & 41 & 84 & 88 & ID & & & & & & & & & & & & & & & & & & & & \\
\hline 13 & ugk14 & 81 & 68 & 91 & 91 & 97 & 90 & 38 & 91 & 96 & 67 & 73 & 100 & ID & & & & & & & & & & & & & & & & & & & \\
\hline 14 & ugk15 & 68 & 59 & 6 & 5 & 6 & 4 & 91 & 5 & 10 & 58 & 59 & 39 & 93 & ID & & & & & & & & & & & & & & & & & & \\
\hline 15 & ugk16 & 20 & 0 & 56 & 56 & 59 & 57 & 60 & 57 & 58 & 1 & 7 & 85 & 68 & 59 & ID & & & & & & & & & & & & & & & & & \\
\hline 16 & ugk19 & 23 & 4 & 58 & 58 & 59 & 57 & 62 & 57 & 60 & 3 & 10 & 85 & 69 & 59 & 4 & ID & & & & & & & & & & & & & & & & \\
\hline 17 & ugk20 & 21 & 6 & 58 & 58 & 60 & 58 & 60 & 58 & 60 & 6 & 7 & 88 & 71 & 60 & 6 & 9 & ID & & & & & & & & & & & & & & & \\
\hline 18 & ugk22 & 20 & 1 & 57 & 57 & 58 & 56 & 59 & 56 & 59 & 0 & 7 & 84 & 67 & 58 & 1 & 3 & 6 & ID & & & & & & & & & & & & & & \\
\hline 19 & ugk23 & 56 & 41 & 75 & 74 & 76 & 75 & 30 & 76 & 78 & 42 & 42 & 91 & 44 & 76 & 41 & 45 & 42 & 42 & ID & & & & & & & & & & & & & \\
\hline 20 & ugk24 & 83 & 74 & 21 & 23 & 29 & 21 & 88 & 21 & 27 & 73 & 75 & 17 & 98 & 25 & 74 & 74 & 75 & 73 & 84 & ID & & & & & & & & & & & & \\
\hline 21 & ugk26 & 81 & 71 & 17 & 17 & 26 & 19 & 92 & 19 & 21 & 72 & 74 & 25 & 98 & 22 & 71 & 73 & 73 & 72 & 82 & 15 & ID & & & & & & & & & & & \\
\hline 22 & ugk29 & 90 & 81 & 34 & 33 & 38 & 32 & 91 & 34 & 39 & 80 & 84 & 12 & 95 & 33 & 81 & 81 & 83 & 80 & 87 & 19 & 24 & ID & & & & & & & & & & \\
\hline 23 & ugk30 & 94 & 86 & 38 & 40 & 44 & 39 & 99 & 39 & 36 & 86 & 83 & 15 & 109 & 42 & 86 & 87 & 87 & 86 & 93 & 20 & 28 & 21 & ID & & & & & & & & & \\
\hline 24 & ugk31 & 24 & 10 & 57 & 56 & 63 & 58 & 56 & 59 & 55 & 11 & 14 & 81 & 64 & 61 & 10 & 14 & 13 & 11 & 38 & 71 & 67 & 77 & 80 & ID & & & & & & & & \\
\hline 25 & ugk32 & 88 & 80 & 42 & 42 & 44 & 41 & 102 & 42 & 44 & 79 & $\begin{array}{l}17 \\
84\end{array}$ & 34 & 107 & 43 & 80 & 80 & 83 & 79 & 91 & 33 & 37 & 29 & 35 & 79 & ID & & & & & & & \\
\hline 26 & ugk33 & 92 & 83 & 33 & 33 & 39 & 31 & 93 & 33 & 38 & 82 & 82 & 13 & 99 & 34 & 83 & 83 & 84 & 82 & 86 & 16 & 23 & 9 & 19 & 79 & 33 & ID & & & & & & \\
\hline 27 & ugk34 & 66 & 62 & 12 & 11 & 14 & 12 & 99 & 13 & 7 & 62 & 61 & 46 & 99 & 13 & 62 & 63 & 64 & 62 & 83 & 32 & 27 & 42 & 39 & 61 & 44 & 42 & ID & & & & & \\
\hline 28 & ugk35 & 92 & 82 & 34 & 34 & 43 & 36 & 94 & 36 & 38 & 83 & 87 & 12 & 101 & 39 & 82 & 84 & 86 & 83 & 88 & 19 & 22 & 13 & 16 & 77 & 32 & 13 & 44 & ID & & & & \\
\hline 29 & ugk37 & 95 & 86 & 40 & 42 & 46 & 41 & 99 & 41 & 38 & 86 & 84 & 19 & 108 & 44 & 86 & 87 & 88 & 86 & 92 & 24 & 28 & 23 & 10 & 80 & 37 & 21 & 42 & 16 & ID & & & \\
\hline 30 & ugk 38 & 62 & 52 & 70 & 69 & 71 & 68 & 88 & 69 & 74 & 51 & 54 & 96 & 89 & 68 & 52 & 53 & 54 & 51 & 73 & 87 & 85 & 93 & 100 & 54 & 98 & 94 & 78 & 95 & 100 & ID & & \\
\hline 31 & ugk39 & 164 & 152 & 187 & 186 & 188 & 185 & 145 & 186 & 191 & 151 & 153 & 190 & 158 & 186 & 152 & 154 & 153 & 151 & 136 & 183 & 186 & 189 & 196 & 149 & 197 & 187 & 195 & 192 & 196 & 176 & ID & \\
\hline 32 & ugk 40 & 22 & 5 & 56 & 56 & 60 & 56 & 60 & 57 & 57 & 5 & 9 & 85 & 68 & 58 & 5 & 8 & 9 & 5 & 41 & 73 & 71 & 81 & 84 & 11 & 80 & 80 & 60 & 83 & 84 & 52 & 150 & ID \\
\hline
\end{tabular}

The cladistics, which show the classifications of organisms based on evolutionary relatedness for 32 sequences, representing species, are presented in Figure 2. The analysis of these sequences gave species primary habitat, as shown in Figure 2. Closely related species in different groups formed have formed a well-supported clades in the $28 \mathrm{~S} r R N A$ gene tree, as shown in Figure 2. For example, T. eriotrephon (Ugk 22) and T. bullosum (Ugk 2) at $90 \%$ bootstrap value, Ugk 23 and Ugk 7 at $90 \%$ bootstrap value.

The phylogenetic tree of $28 \mathrm{~S} r \mathrm{DNA}$ sequences revealed a cluster consisting of anthropophilic and zoophilic. Trichophyton species of T. eriotrephon, Trichophyton benhamiae, and T. bullosum were found in a cluster, which were all zoophilic, a cluster consisting of T. simii, T. rubrum, M. audouinii, and T. tonsurans, which were both anthropophilic and Zoophilic, thus indicating that all of the anthropophilic isolates in this cluster were of zoophilic origin. 


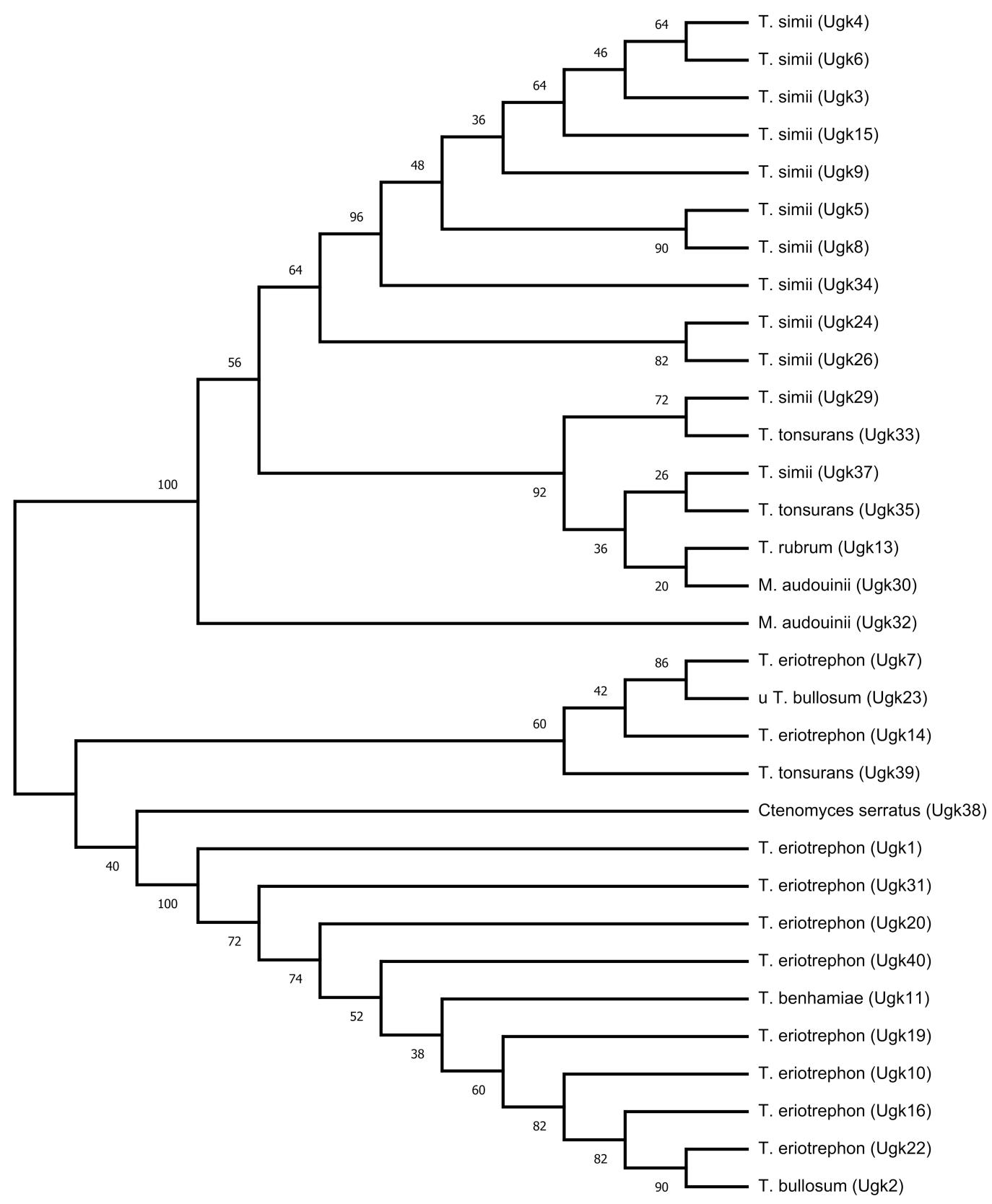

Figure 2. Phylogenetic tree of 32 representative dermatophyte species based on analysis of $28 S r R N A$ gene sequences. The evolutionary history was inferred using the neighbour-joining (NJ) method.

\section{Discussion}

The incidence of dermatophytes isolated from Tinea capitis in this study has found that dermatophyte infection remains a major problem in Africa, especially Nigeria. It is commonly found among families in certain localities, especially primary school pupils, where shelter and hygiene are unhealthy and, as well, northern Nigeria, where animal husbandry is prominent in most homes [12]. It affects children from less than four to ten years of age. The incidence in males, $22(75 \%)$, is three times higher than the incidence in females, $10(25 \%)$ as seen in Table 4 . This might be attributed to the fact that boys' health practices include participating in animal rearing shares of caps, combs, and unsterile blades and clippers during barbing. These results are in agreement with studies by Dogo et al. [4]. Hay and Ashbee [13] also mentioned that erroneous health practices of boys, including the use of other combs and caps, and fewer hair washings than girls, have been associated with dermatophyte infections. Moreover, females have less exposure to sporting facilities 
and institutions [1]. These erroneous health practices are why incidence rate in males was almost thrice the incidence rate in females.

Table 4. Age and sex distribution of forty patients with dermatophytes infection.

\begin{tabular}{ccccc}
\hline \multicolumn{5}{c}{ Age (Years) } \\
\hline Sex & $<5$ & $>\mathbf{5}(\mathbf{6}-\mathbf{1 0 )}$ & Total & Percentage (\%) \\
\hline Males & 8 & 22 & 30 & 75 \\
Females & 4 & 6 & 10 & 25 \\
Total & 12 & 28 & 40 & 100 \\
Percentage (\%) & 30 & 70 & 100 & \\
\hline
\end{tabular}

It is a fact that certain species of dermatophyte species are known to affect certain body areas. For example, T. rubrum is dominantly found in onychomycoses, whereas M. canis is prevalent in Tinea capitis and Tinea corporis. However, in contrast, some species of dermatophytes are never (or are rarely) isolated from a particular dermatophyte infection. This study reveals that $T$. simii and T. eriotrephon were most prevalent in T. capitis where both recorded $37.5 \%$ and $31.25 \%$ prevalence, respectively. Sen and Rasul [14] reported T. simii $(10 \%)$ as one of the prevalent dermatophytes in Tinea capitis. The predominance of Trichophyton species as the causative agent of Tinea capitis (ringworm of the head) is not unexpected. Most studies found T. spp. as the most common etiological agent of Tinea capitis [5]. Trichophyton spp. accounted for $90 \%$ of Tinea capitis in this study. This is higher as compared to a study by Dogo et al. [4], who accounted for 37.8\%, and in agreement with Ahmed et al. [15], who reported $90 \%$ of T. spp. Other T. spp. and M. spp. reported in this study were T. bullosum, T. benhamiae, T. rubrum, T. tonsurans, and M. audouinii, accounting for $6 \%, 3 \%, 3 \%, 9 \%$, and $6 \%$, respectively. Ansari et al. [16] reported $5.4 \%$ for T. benhamiae in T. capitis. A study in Belgium by Sacheli et al. [8] reported a prevalence of T. benhamiae $(2.1 \%)$, which is less than the result obtained. It is worthy to note that Ctenomyces serratus was among the fungi isolated in Tinea capitis infection from this study and no studies have reported the isolation of these fungi from Tinea capitis, to the best of our knowledge. Characterisation of the dermatophyte species causing fungal infection is identified using traditional conventions in Nigeria laboratories. Rapid and accurate identification of dermatophytes, especially using PCR, will provide a platform in prescribing appropriate treatment to the infection. The sequences can be with rDNA sequences from the NCBI/ European Molecular Biology Laboratory (EMBL) GenBank database.

\section{Sequences Analysis}

The use of $28 S$ rRNA region as a target for both phylogenetic analysis and molecular species identification of dermatophytes has provided a better understanding of the taxonomy and evolution of the species. However there are areas of conflict in regards to this genetic marker, because of low nucleotide differences amongst closely related species, such as T. bullosum (Ugk 2)/T. eriotrephon ( Ugk 10, 16, and 22) can be difficult; the discrimination of some closely related species were also reported in a study by Ahamdi et al., [17]. This shows that the target of $28 S$ rRNA requires investigation of additional molecular markers for the further identification of these closely related dermatophytes. Phylogenetic relationships obtained from $28 S$ rRNA gene analysis resulted in the identification of Trichophyton and Microsporum species and their segregation from zoophilic (Trichophyton eriotrephon, Trichophyton bullosum, Trichophyton benhamiae, and Trichophyton simii) and anthropophilic (Trichophyton rubrum, Trichophyton tonsurans, and Microsporum audouinii) species. The length of $28 S$ rRNA sequences (239-347 bp) across these different dermatophyte strains had variations, such that these genes were usually conserved between them.

The differences in sequence length between the different dermatophytes are mainly due to length variation in the non-coding regions of an RNA transcript, or the DNA encoding it, which are eliminated by splicing before translation. The phylogenetic sequence analysis, as shown in Figure 2, shows a cluster consisting of both primary habitat (anthro- 
pophilic and zoophilic) of Trichophyton species, T. eriotrephon (Ugk 7, 14)/T. tonsurans (Ugk 39)/T. bullosum (Ugk 2), supported by a bootstrap value of $99 \%$, and a cluster of zoophilic Trichophyton species of T. eriotrephon (Ugk10, 16, 19, 20, 22, 31, and 40)/T. benhamiae (Ugk 11)/T. bullosum (Ugk 2). There is also a cluster of primary habitat consisting of anthropophilic and zoophilic of both Trichophyton and Microsporum species M. audouinii (Ugk 32 and 30)/T. tonsurans (Ugk 33 and 35)/T. rubrum (Ugk13)/T. simii (Ugk 3, 45, 8, 9, 15, 24, $26,29,34$, and 37) supported by a bootstrap value of $99 \%$. This observation has shown a potential probability that the taxon has an animal-associated ancestry as their primary habitat. The lengths of $28 \mathrm{~S} r R N A$ sequences of the different strains in a cluster consisting of Ugk 1, 31, 20, 11, 40, 19, 10, 16, 22, and 2 ranged from 247 to $250 \mathrm{bp}$ (Table 3); thus, indicating that these species are very closely related. The biodiversity of differentiated species $T$. eriotrephon (Ugk 16) and T. bullosum (Ugk 2) showed 90\% (0 bp difference) similarity. Our data suggest that 28S rRNA is not useful for species differentiation of T. eriotrephon (Ugk 22) and T. bullosum (Ugk 2), which are on the same internode (bootstrap value 90\%) and, thus, needed an additional marker for accurate identification.

The $28 \mathrm{~S} r R N A$ gene sequence analysis showed that most of the anthropophilic strains were from animal origins. As reported by some researchers, hedgehogs, chicken, horses, and guinea pigs are carriers of these dermatophyte strains. Northern Nigeria is into rearing of these animals and, as such, possible transmission of these strains to humans. The close relationship between the strains of all these species (Zoophilic and anthropophilic) in the phylogenetic tree is also supported by $28 S r R N A$ gene sequence data.

\section{Conclusions}

Most species causing fungal infections, especially Tinea capitis in Nigeria, are identified using traditional conventional methods, which are generally time consuming with wrongful identification of the causative species, thus necessitating for a rapid and accurate identification and characterisation in providing standard and appropriate prescription treatment. PCR targeting the $28 \mathrm{~S} r \mathrm{DNA}$ region is considered as a gold standard in the identification and characterization of dermatophytes from human skin [18]. There are studies that describe the extraction of DNA directly from human samples (nails) for the identification of the infecting dermatophytes [19]. The use of amplified fragments of the 28S-rDNA gene contain regions of differentiation amongst these species [20]. These facts have provided a potential use of this marker in a confirmatory technique for dermatophytespecific PCR targeting the $28 S r R N A$ gene, in characterisation and accurate identification, especially in Tinea capitis infection [21]. Based on the above proven facts, we consider $28 \mathrm{~S}$ rRNA PCR as the gold standard for this study. To the best of our understanding, this study is the first of its kind in Sokoto to have successfully deposited nucleotide sequences of studied dermatophyte strains into the GenBank database.

Author Contributions: Conceptualization, H.Y.U.-k. and J.O.E.; methodology, H.Y.U.-k., J.O.E., J.A.O. and O.S.O.; software, H.Y.U.-k., J.O.E., J.A.O. and O.S.O.; validation, H.Y.U.-k., J.O.E., J.A.O. and O.S.O.; formal analysis, H.Y.U.-k., J.O.E., J.A.O. and O.S.O.; investigation, H.Y.U.-k.; resources, H.Y.U.-k.; data curation, H.Y.U.-k. and J.O.E.; writing-original draft preparation, H.Y.U.-k.; writingreview and editing, H.Y.U.-k.; visualization, H.Y.U.-k., J.O.E., J.A.O. and O.S.O.; supervision, J.O.E., J.A.O. and O.S.O.; project administration, H.Y.U.-k.; funding acquisition, H.Y.U.-k. All authors have read and agreed to the published version of the manuscript.

Funding: This research received no external funding.

Institutional Review Board Statement: The study was conducted according to the guidelines of the Declaration of Nigeria, and approved by the Ethics Committee of Sokoto State Ministry of Health (SKHREC/088/017, 29 December 2017).

Informed Consent Statement: Informed consent was obtained from all subjects involved in the study. 
Acknowledgments: We thank all staff at Usmanu Danfodiyo University, Sokoto, Nigeria, especially personnel in the Molecular Biology Laboratory at the Faculty of Veterinary Medicine, Usmanu Danfodiyo University, Sokoto.

Conflicts of Interest: The authors report no conflict of interest. The authors alone are responsible for the content and the writing of the paper.

\section{References}

1. Adeiza, S.S.; Onaolapo, J.A.; Olayinka, B.O. Prospective nucleotide sequence analysis of methicillin resistant Staphylococcus aureus isolates from Sokoto state. Microbiol. Med. 2020, 35. [CrossRef]

2. Ahmadi, B.; Mirhendi, H.; Makimura, K.; de Hoog, G.S.; Shidfar, M.R.; Nouripour-Sisakht, S.; Jalalizand, N. Phylogenetic analysis of dermatophyte species using DNA sequence polymorphism in calmodulin gene. Sabouraudia 2016, 54, 500-514. [CrossRef] [PubMed]

3. Ahmed, I.; Ahmed, Z.; Nasreen, S. Prevalence of tinea capitis and asymptomatic carriage amongst school going children. J. Pak. Assoc. Dermatol. 2017, 16, 215-219.

4. Ansari, S.; Hedayati, M.T.; Zomorodian, K.; Pakshir, K.; Badali, H.; Rafiei, A.; Ravandeh, M.; Seyedmousavi, S. Molecular characterization and in vitro antifungal susceptibility of 316 clinical isolates of dermatophytes in Iran. Mycopathologia 2016, 181, 89-95. [CrossRef] [PubMed]

5. $\quad$ Arenas, R.; del Rocío Reyes-Montes, M.; Duarte-Escalante, E.; Frías-De-León, M.G.; Martínez-Herrera, E. Dermatophytes and Dermatophytosis. In Current Progress in Medical Mycology; Springer: New York, NY, USA, 2017; pp. 381-425.

6. Cai, W.; Lu, C.; Li, X.; Zhang, J.; Zhan, P.; Xi, L.; Sun, J.; Yu, X. Epidemiology of superficial fungal infections in Guangdong, southern China: A retrospective study from 2004 to 2014. Mycopathologia 2016, 181, 387-395. [CrossRef] [PubMed]

7. Chisanga, M.; Muhamadali, H.; Ellis, D.I.; Goodacre, R. Enhancing disease diagnosis: Biomedical applications of surface-enhanced Raman scattering. Appl. Sci. 2019, 9, 1163. [CrossRef]

8. Dogo, J.; Afegbua, S.L.; Dung, E.C. Prevalence of Tinea capitis among school children in Nok community of Kaduna state, Nigeria. J. Pathog. 2016. [CrossRef] [PubMed]

9. Gupta, A.K.; Mays, R.R.; Versteeg, S.G.; Shear, N.H.; Piguet, V. Update on current approaches to diagnosis and treatment of onychomycosis. Expert Rev. Anti Infect. Ther. 2018, 16, 929-938. [CrossRef] [PubMed]

10. Gyimah, N. Social Housing Systems: Perspective of Ghana, Nigeria, United Kingdom, and Netherland. Niger. UK Netherland 2020, 1, 11-12. [CrossRef]

11. Hay, R.J.; Ashbee, H.R. Fungal infections. In Rook's Textbook of Dermatology, 9th ed.; John Wiley \& Sons: Chichester, UK, 2016; pp. 1-110.

12. Kim, J.Y.; Choe, Y.B.; Ahn, K.J.; Lee, Y.W. Identification of dermatophytes using multiplex polymerase chain reaction. Ann. Dermatol. 2011, 23, 304-312. [CrossRef] [PubMed]

13. Mochizuki, T.; Takeda, K.; Anzawa, K. Molecular markers useful for intraspecies subtyping and strain differentiation of dermatophytes. Mycopathologia 2017, 182, 57-65. [CrossRef] [PubMed]

14. Moreno, L.F.; Ahmed, A.A.; Brankovics, B.; Cuomo, C.A.; Menken, S.B.; Taj-Aldeen, S.J.; Faidah, H.; Stielow, J.B.; Teixeira, M.; Prenafeta-Boldú, F.X.; et al. Genomic understanding of an infectious brain disease from the desert. G3 Genes Genomes Genet. 2018, 8, 909-922. [CrossRef] [PubMed]

15. Moser, S.A.; Wicker, J. Commercial Methods for Identification and Susceptibility Testing of Fungi. In Commercial Methods in Clinical Microbiology, International ed.; John Wiley and Sons: Hoboken, NJ, USA, 2016; pp. 214-271. Available online: https:/ / onlinelibrary.wiley.com/doi/abs/10.1002/9781119021872.ch13 (accessed on 4 March 2021).

16. Sacheli, R.; Menatong, X.; Labarbe, C.; Crützen, C.; Harag, S.; André, J.; Evrard, S.; Lagrou, K.; Laffineur, K.; Rousseaux, D. Belgian national survey on tinea capitis: Epidemiology and molecular investigations. Mycoses Suppl. 2019, 476. Available online: https:/ / orbi.uliege.be/bitstream/2268/239981/1/Timm\%202019\%20Sacheli\%20survey\%20031019.pdf (accessed on 4 March 2021).

17. Sánchez, M.J.I.; Pico, A.M.P.; Tejedor, F.M.; Sánchez, M.J.I.; Acevedo, R.M. Using a polymerase chain reaction as a complementary test to improve the detection of dermatophyte fungus in nails. J. Am. Podiatr. Med Assoc. 2014, 104, 233-237. [CrossRef] [PubMed]

18. Sen, S.S.; Rasul, E.S. Correspondence-Dermatophytosis in Assam, India. 2006. Available online: https://www.ijmm.org/article. asp?issn=0255-0857; year=2006; volume=24;issue=1; spage=77; epage=78; aulast=Sen (accessed on 4 March 2021).

19. Shimoyama, H.; Satoh, K.; Makimura, K.; Sei, Y. Epidemiological survey of onychomycosis pathogens in Japan by real-time PCR. Med Mycol. 2019, 57, 675-680. [CrossRef] [PubMed]

20. Willinger, B. What Is the Target? Clinical Mycology and Diagnostics. In Clinically Relevant Mycoses; Springer: New York, NY, USA, 2019; pp. 3-24.

21. Wingfield, D.S.S.; Hald, M.; Arendrup, M.C.; Hjorth, S.V.; Kofoed, K. Darier Disease Complicated by Terbinafine-resistant Trichophyton rubrum: A Case Report. Acta Derm. Venereol. 2017, 97, 139-140. 